\title{
FIFTH AMENDMENT CONSOLIDATION OF THE 1945 CONSTITUTION OF THE REPUBLIC OF INDONESIA
}

\author{
Mhd. Ansor Lubis \\ Faculty of Sharia and Law, North Sumatra State Islamic University \\ ansorlubis88@gmail.com
}

\begin{abstract}
Consolidation is an action taken to strengthen, unite and strengthen the relationship of national unity and unity if it is associated with the fifth amendment of the 1945 Constitution of the Republic of Indonesia. The question that the author discusses in this study first is the desire of the authorities to make the fifth amendment to the 1945 Constitution of the Republic of Indonesia through consolidation? As for the conclusion of this study that in the framework of the Consolidation of the Fifth Amendment of the 1945 Constitution of the Republic of Indonesia will bring the Indonesian people to a better and orderly future and there will be no more cracks and consolidation will be realized in accordance with the rules of developed and modern countries such as the United States of America as a comparison. The method used in this study is a normative juridical legal research method. The fifth amendment is able to be the basis of national consolidation, because the state actors agree that the 1945 Constitution of the State of the Republic of Indonesia is used as the Grund Norm, will be able to bring prosperity to the nation and state, with this fifth amendment able to bring and develop an Indonesian state that consists of various kinds ethnicity, religion, race and culture.
\end{abstract}

Keywords: Consolidation, Amendment, Constitution, Presidential System.

\section{INTRODUCTION}

The development of democratization in Indonesia has provided an update to the political structure of the state administration in this republic, one of which concerns changes in the general election of both the President and Vice President and also the election of members of the People's Legislative Assembly, the Regional Representative Council and also the Regional People's Representative Council directly and concerning their relationship with other state institutions, in this case the People's Consultative Assembly. ${ }^{1}$ Amendments to the Constitution of the Republic of Indonesia in 1945 were the culmination of a fundamental change achieved by the power of the people after the New Order government. Amendments to the 1945 Constitution of the Republic of Indonesia have made major changes, especially in the general election.

History records that the general election was a milestone in Indonesia's postreform democratization namely in 2004 Indonesia chose the President and Vice President and also elected legislative members, before 2004 the general election only

${ }^{1}$ National Law Guidance and Human Rights Development Agency. RI Study of Laws Problems of Laws Election of President and Representative of Vice President Directly, (Jakarta: Legal Review Team on Legal Issues Election of President and Vice President directly, 2004), p. 1. 


\section{NOMOI}

\section{LAW REVIEW E-ISSN:2722-3663

chose the people's representatives in the DPR, DPD, Provincial DPRD and Regency / City DPRD and tradition. This has been going on since the first election in 1955 until the new order in 1999. Changes were alternating and there came a time of reformation until now many changes are sticking out in the state, one of which is the desire of the MPR to make changes to the fifth amendment of the 1945 NRI 1945 after the first amendment was made on 19 October 1999, the second amendment was in 2000, then the third amendment was on 9 November 2001, and the fourth amendment was in 2002.

The thought of the change was put forward by the DPD RI who proposed 10 points on the amendments presented at the fifth amendment discussion meeting attended by the Chairperson of the MPR Faction from PDIP, PKB, NASDEM and Deputy Chairperson of the Hanura MPR Faction. These strategic issues were raised by the DPD RI as the main points of the 1945 NRI amendment, that are: ${ }^{2}$

1. Strengthening the presidential system;

2. Strengthening representative institutions;

3. Strengthening regional autonomy;

4. Individual presidential candidates;

5. Sorting national and local elections;

6. Previlegiatum Forum;

7. Optimizing the role of the Constitutional Court;

8. Addition of articles on human rights;

9. Addition to the Chapter of the State Commission;

10. Sharpening Chapters on Education and the Economy

2 www.liputan6.com, accessed on friday, 06 september 2019 at 11: 28 pm.
The three factions of the People's Consultative Assembly which wanted and supported the fifth amendment to the 1945 Constitution of the Republic of Indonesia NRI were aimed at restoring the MPR's function as the highest state institution above the legislative, executive and judiciary bodies. Golkar Faction RullyChairulAzwar wants to re-establish the function of the MPR as the highest institution, the United Development Party (PPP) faction said the same thing as the Golkar party, as well as the United Development Party faction.

Researchers from the Indonesian Institute of Sciences SyamsuddinHaris, (LIPI), criticized the 1945 constitution of the fourth amendment having many shortcomings because it is still patchy, the amendment process is only directed according to demand, short, not systematic and not patterned, and the quality and substance is incoherent and inconsistent. However, SyamsuddinHaris refused if there were various weaknesses in the 1945 Constitution of the Republic of Indonesia. The amendment results were used as a reason to return to the 1945 Republic of Indonesia according to him. the goals of democracy are based on the substance, justice and welfare of the people. ${ }^{3}$

With this effective government, the Indonesian people have chosen a democratic government system for the change of power every five years in accordance with the 1945 Constitution of the Republic of Indonesia with the general election model as regulated in Law

${ }^{3}$ www.hukumonline.com, accessed on Friday September 6 2019, at 11:50 a.m. 


\section{NOMOI}

\section{LAW REVIEW E-ISSN: 2722-3663

Number 7 of 2017 Concerning General Elections, the election of the model is considered the best among other forms in the world. The thinkers and policy makers in choosing the model through debate and argumentation are quite tough and long. Seeing the history of determining the change of leaders takes place democratically, in accordance with the theories and ideas of the designers of the state, observers and experts on state governance highly respect and appreciate the implementation of direct, general, free, secret, free, and fair elections (luberjurdil), the implementation has been running for almost 20 years.

The implementation of elections in 2019, especially the presidential and vice presidential elections, are viewed from different sides, due to different perspectives, causing political temperatures to warm up, two camps claiming the truth on each side. The distance between the two camps is getting wider, because of the different perspectives and interests. In the future there needs to be a movement to unite two different views for the interests of the nation and state of the Republic of Indonesia. According to Burhanidin Muhtadi, there were injuries to the nation, accompanied by a democratic party, during the course of democracy, only in 2019 was the political flow of the post-election presidential domain. The election of the five-year power change that has been modified in Indonesian style is very suitable to the climate and culture of Indonesia, precisely in the future there is a thought for the fifth amendment which is more perfecting the state rules that are better and arranged according to modern state rules and state administration law.

The direction of the development of the nation's progress and structuring of the constitution as the root of the foundation of the ground, is one of the choices of civilian thinkers, towards a nation that is developed with civilization and based on honesty and ethics ethics, fair and civilized humanity, the unity of Indonesia, populist and led by wisdom in the deliberation of representative representation. and social justice for the people of Indonesia, if there are ideas to return to the 1945 Constitution of the Republic of Indonesia in a pure and consistent manner as suggested in the DPD session. So it is very necessary to be questioned with logical and empirical arguments. In the book Understanding Political Power by MukhtarHabodin, it is stated that there is a logic of the ruler to maintain his power, the way is by eliminating old regulations, especially in the political field which is detrimental to the ruling leader. The regulation will be replaced with a new one that benefits the ruler even though two Presidential candidates have not been determined, but there are efforts towards the replacement to move to the status quo of previous power. This means that it will be returned to the authority of the new government which has been in power for 32 years

As a result of the strength of the two candidates and the insistence of two supporters of the candidate is so strong and conical, the fear of the threat of a very large nation split. In the future, we need to consolidate two businesses into one with the same goal, namely a business that is merged so that it can benefit both parties, 
which have a common goal and to improve joint performance. This is not far from an organization or business that wants to be fast in the development process of an organization, so it is like looking for cooperation but still with interrelated goals. Consoidation is a unifier for those who do not fuse and form for the better. ${ }^{4}$

The author tries to explain the nation's problems that currently occur namely the desire of the authorities to make the fifth amendment to the 1945 Constitution of the Republic of Indonesia through consolidation. The method used in this study is normative juridical research namely legal research, by examining the doctrines or sources of primary and secondary law, such as the 1945 Constitution of the Republic of Indonesia. The Basic Law as the primary source which is then analyzed with historical and philosophical models.

\section{METHOD}

Legal research is a process to find the rule of law, legal principles, and legal doctrines to address the legal issues at hand. ${ }^{5}$ The type of legal research used in this study is normative juridical. The data used are secondary data using primary legal materials, secondary legal materials, and tertiary legal materials.

\section{DISCUSSION}

The Republic of Indonesia Regional Representative Council (DPD) once had the direction of changing the

\footnotetext{
4 www.google.com./amp/s/kbbi.web.id Friday September 6 2019, at 6:14 p.m.

5 Peter Mahmud Marzuki, Penelitian Hukum, (Jakarta: Kencana Prenada Media Group, 2005), hlm. 35.
}

1945 Constitution of the Republic of Indonesia. The strategic issues raised by the DPD RI were ten points: first Strengthening the presidential system with the arguments of the Indonesian people must clarify and strengthen the implementation of a presidential government system, in order to guarantee national political stability based on characteristics and historical background of the Indonesian nation. Second, strengthening the representative institutions in order to improve the quality of policies in terms of the degree of representation in each formation of legislation, and the mechanism of interchamber checks and balances is needed in the legislative function of the representative institutions. Thirdly, strengthening regional autonomy, namely the state needs to regulate the pattern of relations between the central and regional levels, as well as giving more space to carry out its autonomy. The fourth is the idea of the possibility of a candidate for President and Vice President from individuals, so that it is not only carried through political parties, the hope is to open up opportunities to be elected as citizens of course with regulated and complete requirements. The fifth is about the grouping between national elections and local elections, namely the election of national elections with local elections technically intended to make the election simpler, while mapping the election issues nationally and locally. Sixth, a legal certainty is needed for state officials who face the judicial process, with the hope that is not too protracted in dealing with the judicial process that is required Previlagetium Forum. Seventh Strengthening the role of the 
Constitutional Court (MK), as a court of law (court), there needs to be more optimal authority in terms of testing legislation, deciding on the authority of state institutions, deciding election disputes over general election results as well as post-conflict local elections and constitutional complaints ). Eighth addition of articles concerning human rights.because the spirit that is built is that the state must make every effort to realize human rights guarantees that have been recognized in the convention as a form of the realization of the rule of law. In particular it is necessary to regulate the rights of women, workers and the press. Nine additional chapters on state commission institutions. Tenth is the sharpening of the chapter on education and the economy. The reason is because the state needs to affirm the guarantee of citizens' rights in obtaining education and training.

The state also needs to exercise control over the branches of production which are important to the state and / or control the livelihoods of many people for the greatest prosperity of the people.

The ten points proposed by the DPD RI in the opinion of the author, that the first point, still has not been refined, the choice in the presidential system has been implemented but not yet one hundred percent, because at this time parliament is still interfering in presidential power, so that the election of President and Vice President cannot compile the cabinet in accordance with the wishes of the elected president, but the ruling party in parliament in parliament still participates.

The same thing was also addressed by Professor of the University of North Sumatra (USU) Prof. Damayanti Lubis
"The amendment has been very urgent, especially in the constitutional system, namely the presidential government system with the aim to strengthen the elected government, namely Ir. JokoWidodo and Prof. Dr. KH Ma'ruf Amin, MA is not encouraged by parliament, so it cannot result in programs that have been prepared by the government late, so strengthening the presidential system is done so that government programs are run quickly and effectively, because according to him there are some rules and legislation new and will potentially weaken the presidential system in the field application.

The second note to date the press freedom commission, has not been accommodated in a body regulated in the constitution, even though the DPD RI's proposal to include new institutions in the Constitution in various countries is important, because the Press is the fourth pillar of democracy. The tenth proposal according to the author is also not yet fully accepted in the fourth amendment constitution, considering education and the economy, especially in the fields of mining, infrastructure until now still controlled by foreigners.

While Professor of Constitutional Law at the University of Indonesia (UI), JimlyAsshiddiqie stated, in the context of consolidating the post-reform constitutional system, it was time for the fifth amendment to the 1945 Constitution of the Republic of Indonesia to be seriously considered. The idea of the state administration expert is based on strong arguments, for example, because during 


\section{NOMOI}

\section{LAW REVIEW E-ISSN: 2722-3663

the fourth amendment, the country's constitution was not yet perfect. ${ }^{6}$

"Unfortunately, it is not realized that we need to consolidate the constitutional system, the excess (power) must be reduced, the less even if added. Many rights must be repaired. We see it everyday because of the system settings that we have to fix. So, I support the idea of a fifth amendment for the consolidation of the constitutional system. Certainly not only DPD (Regional Representative Council)

Jimly Asshiddiqie stated, in the context of consolidating the constitutional system of the post-reformation of the Indonesian nation, it requires an in-depth study to perfect the results of constitutional changes that were practiced so far. That practical reason is the basis for JimlyAsshiddiqie to move towards the fifth amendment to the 1945 Constitution of the Republic of Indonesia.

According to Jimly Asshiddiqie, now it is applied in practice as a presidential system but, in reality, it is not purely presidential because the parliament is still very influential in determining the direction of the President and Vice President in making decisions and policies. The language used by Jimly Asshiddiqie is a parliamentary presidential system, similarly said by Mahfud MD, that the current election model in electing the President is not a change of power, but a presidential election is a change of leader. The argument is because the President-

6 Jimly Ashidiqie, "Presidential System for Parliamentary Taste", State Dialogue in the DPD Building, Parliament Complex, Senayan", Jakarta, accessed on Friday 06 September 2019 at 22: 53 pm elect cannot freely determine his cabinet, and is still being driven by the supporting party.

While researchers from the Indonesian Institute of Knowledge (LIPI), Samson Haris, stated that after the reforms that had developed dynamically made Indonesia an efficient and effective democratic state system. Haris proposed to carry out a systemic consolidation through a review of several issues of the 1945 Constitution after the fourth amendment including the work mechanism of the People's Representative Council (DPR), the Regional Representative Council (DPD) and the President, including the division of tasks between the People's Representative Council (DPR), and the Regional Representative Council (DPD), which is considered not in accordance with the modern state administrative model. ${ }^{7}$

The fifth amendment must be implemented, especially concerning presidential system issues to be clear and certain. not all the contents of the constitution have been changed and amended with the new model, the most important thing is that the changes should not be regarded as only for the momentary political interests of certain political groups, because these changes are according to Jimly is an urgent matter important issues for a better future statehood . The deregulation or reorganization of the constitution by prioritizing the fifth constitution is a common interest rather than a momentary interest therefore the Indonesian nation

\footnotetext{
7 Jurnal Hukum Kenegaraan, Vol. 2,
} No. 1, Juni 2019, Konsolidasi Kebangsaan dan Lembaga Negara by APHTN-East Java. 


\section{NOMOI}

\section{LAW REVIEW E-ISSN: 2722-3663

needs consolidation, and requires a rearrangement of state administration.

The most important amendment according to Haris is about the division of tasks between the House of Representatives and the tasks carried out by the Regional Representative Council, it should not be based on a double check system, if the division of tasks is based on fields, it will create two groups of laws. There are groups of laws that are worked on by the DPR plus DPD members. On the other hand there are laws produced by the House of Representatives, as a result of two high-level state institutions that carry out the same task the dualism of the act of the law appears. This is a problematic of the legal system.

The division of tasks between the DPR and the DPD should be based on a double check system, and with supervision. If the division of tasks is based on procedures, then there is no need to happen that the laws relating to the regions are carried out by DPD members and the laws that are not related to the regions are carried out by members of the DPR. This model is not right, because one of the amendments is the existence of the DPD, if its function is still in the current Constitution, then its function is the same as there is no meaning that the DPD is not needed in the model of making rules that favor the people. The first option DPD was abolished because its function was the same and had been taken by the House of Representatives.

The author compares with the United States of America that those entitled to submit legislation were worked on by the committee, House of Representatives (HoR), Senate, and at the last stage the President took part in the ratification of laws worked by the government and parliament, should those laws do not meet the requirements then must be over right in the Senate. both do the same thing but the difference is the procedure and whether it is equally strong or not is a matter of choice. While the fifth amendment to the 1945 Constitution of the NRI according to the chairman of the DPD group BambangSoeroso regarding the functions, duties and authority of the DPD, the proposed amendment to the five 1945 Constitution of the NRI which is now proposed by the DPD involves strengthening the central issue, namely strengthening the presidential system, strengthening the representative institutions, and strengthening regional autonomy.

"This proposed constitutional amendment is no longer partial, but comprehensive. DPD has completed the proposed text of the fifth comprehensive amendment to the 1945 Constitution. The discussion and formulation with seventy-five tertiary institutions throughout Indonesia, which were assisted included prominent people or experts and figures. The fifth amendment to the Constitution of the Republic of Indonesia, solutions to problems and needs of Indonesia. $^{8}$

After the fourth amendment of the 1945 Constitution the Republic of Indonesia underwent a fundamental

8 Bambang Soeroso, Focus Group Discusion, International Wildlife Museum \& Rahmad Gallery, Jl S Parman Number 309 Medan, North Sumatra, Friday 18 March 2018, accessed on Saturday Saturday 7 September 2019. 
change, namely creating a check and balances mechanism in the government system as a control of each power that leads to separation of power. The mechanism is a presidential system phenomenon, because it is essentially for the development and development of democracy. To create checks and balances, a representative institution was born which actually has a noble purpose and aim, which is to become a "bridge" for the aspirations and interests of the people and regions at the national level called DPD. Even though the 1945 Constitution of the Republic of Indonesia has changed four times, in practice, the functions, duties and authority of the DPD are still very marginal in fighting for the aspirations and interests of the people and in the direction.

Changes to the 1945 Constitution of the Republic of Indonesia, which has changed four times, according to Bambang, still leave social, national and state issues, one of which is the existence of the DPD so that in the future it will require changes to five constitutions for the birth of a complete constitution for the present and the future. The 1945 Constitution of the Republic of Indonesia still does not accommodate the urgent and strategic needs of the people, nation and state. Therefore it is natural that the discourse of rethinking the needs and benefits of safeguarding the constitution.

Times have indeed changed, these changes must follow the components of the nation that used to use the 1945 NRI Constitution, RIS 1949 Constitution, the Provisional Constitution and returned to the 1945 Constitution and amendments were made by the founding fathers of the nation so that changes to the 1945 NRI constitution again occurred due to adjusting community needs for the creation of people's welfare as mandated by the constitution. These needs have to adjust to what is in the past is not perfect yet perfect at this time because it must be corrected, what was considered sufficient with the articles of the Constitution in fact not yet able to become the basis of the nation and state so the basic law must be changed again for the fifth amendment.

In the future, inevitably there will be more fundamental changes in the Republic of Indonesia's constitutional system for mutual progress, the author believes that the fifth amendment to the 1945 Constitution of the Republic of Indonesia is carried out with the aim of building and developing democracy for the people's welfare. One direction of the change is so that the holders of the people's mandate, such as the people's representatives in the DPD function optimally and do not overlap between the DPR in carrying out their duties, the author also believes that weaknesses in the constitution make it difficult for the position and role of the DPD to carry out functions, duties, and authority so far. The direction and purpose of the fifth amendment must maximize the functions, duties and roles of the DPD, both leaders and members to help the community solve problems, especially in submitting draft laws so that they become laws. In my opinion, the writer also said that the DPD did not yet have the maximum role, whereas the DPR had complete power to compile the products of legislative oversight and budgeting. 
The fifth amendment to the 1945 Constitution of the Republic of Indonesia the basis of consolidation

National consolidation is indeed needed and the fifth amendment is the requirement because it is the basis. If traced in the history of state organization, it is concluded that the founders of the state actually have explicitly stated that the 1945 Constitution of the Republic of Indonesia is a temporary constitution. In fact, Sukarno called it the Constitution or Revolutie Ground Wet. Because of the delay, almost half a century (1945-1949 and 1959-2002), the history of Indonesian state administration was trapped in the temporary nature of the 1945 Constitution of the Republic of Indonesia. ${ }^{9}$

The Republic of Indonesia sovereign power maintains a temporary constitution because it benefits the rulers of the essence of the 1945 Constitution which is temporary which is evident from the many rules in the 1945 Constitution which are multi-interpreted. However, the interpretation that must be accepted is the interpretation issued by the President as the central power (executive heavy). The tendency of executive heavy in the 1945 Constitution of the Republic of Indonesia is a reality in terms of the formation of state institutions. Formation of state institutions except presidential institutions is carried out by law. ${ }^{10}$

${ }^{9}$ Saldi Isra: "Konsitusi Baru Melalui Komisi Konsitusi: Memastikan Arah Reformasi Konsitusi", Jurnal Analisi CSIS, tahun XXXI/2002, No. 2, p. 233

${ }^{10}$ Muhammad Ridhwan, UUD 1945 Kekuasaan Eksekutif Lebih Menonjol (executive heavy), (Jakarta: Haji Masabung, 1998), p. 21.
As a result of the formation of state institutions by law, the President has more dominant power than other state institutions. Because with the power of forming legislation in the President, of course the contents of the draft laws that are designed will benefit the President while the role of the DPR, is limited to approving or rejecting the bill proposed by the executive. The right of members of the House of Representatives to submit a bill is complicated by the many requirements in the order. On this basis, it is understandable if in a law that was born because of the political will of the President (executive). So it has implications in the practice of state administration with the birth of an authoritarian government. ${ }^{11}$

The 1945 Constitution of the Republic of Indonesia as a law governing the Indonesian state organization which establishes the constitutional structure, provides the basis for the legitimacy of the existence of state institutions. When viewed from the substance set out in it, it has not yet fully realized what is the goal of establishing a constitution (UUD) for a country. The basic principles and concept of state adopted in the opening of the 1945 Constitution have not been clearly formulated in the articles of the Constitution, so that in practice there is room to provide interpretation of the provisions of the article according to the wishes of the state administration.

Changes to the 1945 Constitution of the Republic of Indonesia from the first amendment of 1999 to the fourth of 2002 constitute a unity. Changes are made by

${ }^{11}$ Moh, Mahfud MD, Politik Hukum di Indonesia, (Jakarta: LP3ES, 1998), p. 309-317 


\section{NOMOI}

\section{LAW REVIEW E-ISSN: 2722-3663

loading in each MPR product with amended material, the formulation of the sound of articles or paragraphs of change without quoting the sound of the article or verse that was changed. By only mentioning and formulating the original article or verse it is replaced by the sound.

This method of change is intended to maintain the original structure of the 1945 Constitution. If changes are made to the addition of verses to the old or amended article, then the verses will be connected to the existing paragraph. Thus the numbering of verses that have been there before one very important phenomenon after the changes to the 1945 Constitution of the Republic of Indonesia is the spread of independent state institutions in the Indonesian constitutional system. These institutions are formed on a different legal basis, both with the constitution and laws, the different legal basis shows that the independent state institutions are formed based on partial, incidental issues and as a specific answer to the problem that is being faced. Basically, the formation of independent state institutions in Indonesia was formed because existing state institutions could not yet be given a solution and to resolve existing problems when demands for change and improvement became more prominent. Along with the emergence of the era of democracy. In addition, the birth of independent countries is a form of public distrust of the existing institutions in solving the problems faced by the state administration. $^{12}$

12 T.M. LuthfiYazid, "National Commissions in the Context of the Ideals of the Rule of Law", (paper delivered in the Limited Discussion in the Aryaduta Hotel, Jakarta, September 9, 2004), p. 2.
A change in political configuration from authoritarianism to democracy applied in a country. Absolute demands a shift in the management of power from what was originally personal to impersonal. At the same time, this resulted in the division of state power which was previously considered to be an established doctrine to be corrected and it was felt that it was no longer sufficient to just clarify it into government power, the power of making laws, and judicial power. Separation of power (separation of power) between state institutions embraced by the 1945 Constitution of the Republic of Indonesia and a shift in the authority of state institutions that occurred after the amendment to the 1945 Constitution.

\section{The Principle of the Separation of Power}

Separation of powers before the Amendment to assess whether the 1945 Constitution of the Republic of Indonesia adheres to the separation of powers or the distribution of power, the criteria established by Ivor Jenning can be used. Jenning said that the separation of power (separation of power) can be seen from a material and formal angle. The separation of power in the material sense means that the distribution of power is maintained firmly in the tasks of state which characteristically shows the existence of the separation of power in three parts, namely legislative, executive and judiciary. Conversely, if the distribution of power is not strictly maintained, it is called the separation of powers in the formal sense. ${ }^{13}$

13 Moh.Kusnardi, Harmaily Ibrahim, Hukum Tata Negara Indonesia, (Jakarta: Pusat 


\section{NOMOI}

\section{LAW REVIEW E-ISSN: 2722-3663

According to Moh.Kusnardi and Harmaily Ibrahim, the separation of powers in the material sense can be called the separation of powers. While the separation of power in the formal sense is called the division of power Jimly Assiddiqiqie believes that the separation of powers can be horizontal and vertical. In the horizontal sense means power is divided into functions that are reflected in the institutions of equal and mutually balancing countries (Checks and Balances). ${ }^{14}$

Whereas the separation of powers is vertical in the sense that the manifestation of power is distributed vertically down to high state institutions under the institution of sovereignty of the people. Based on the criteria made by Jenning, Kusnardi and Harmaily concluded that the 1945 Constitution (before the amendment) did not adhere to the power separation system (TriasPoilitica) as taught by Montesquieu, but rather to adhere to a power sharing system because: 1) the 1945 Constitution did not sharply limit, that each power must be exercised by a certain organ / body which may not interfere with each other. 2) The 1945 Constitution of the Republic of Indonesia does not limit the power divided into three parts and also does not limit the distribution of power carried out by three organs / bodies only. 3) The 1945 Constitution does not divide the people's

Studi Hukum Tata Negara FH UI, 1998), p. 143.

${ }^{14} 3$ Jimly Ashiddiqie, Format Kelembagaan Negara dan Pergeseran Kekuasaan Dalam UUD 1945, (Yogyakarta: FH UII Press, 2005), hlm. 35 power exercised by the MPR (Article 1 paragraph 2) to other state institutions. ${ }^{15}$

Likewise Jimly, who stated that so far (before the amendment: pen), the 1945 Constitution adheres to the understanding of power sharing that is vertical, not horizontal separation. People's sovereignty is considered to be fully realized in the MPR forum which can be interpreted as the highest institution or as the highest forum. From here, certain functions are distributed as the duties and authorities of the higher state institutions below, namely the President, Parliament, MA, and so on. In the perspective of the distribution of power that is vertical, the principle of equality and balance of power is not primary.

Therefore, in the old 1945 Constitution (the 1945 Constitution before the amendment: pen) there was no strict separation from the legislative and executive functions. In the old system, the main function of the DPR was more of a supervisory body than a legislative body in the true sense.

\section{Separation of Power Post Amendment to the 1945 Constitution}

One of the most important of the rule of law is the distribution of power or separation of powers within the state. The doctrine of separation of power (separation of power) has shown a variety of styles in various countries. The reality shows that different government systems have developed this doctrine in different ways, depending on different ways, depending on

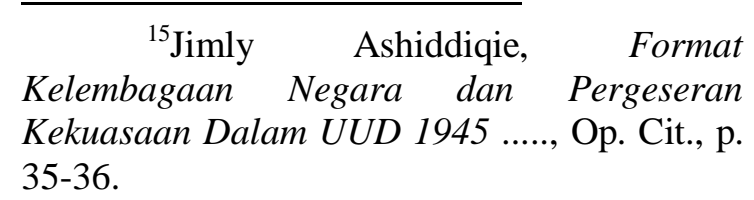




\section{LW REVIEW E-ISSN: 2722-3663 \\ LAW REVIEW Volume 1, Issue 1, May 2020 \\ the potitieal praetiees, habits and legat}

principles adopted by a country. Even

Marshall states that: "The phrase" separation of power "is, however, one of the most confusing in the vocabulary of political and constitutional thought historians and political scientists". Meaning: The expression of separation of powers is very confusing in the vocabulary of political and constitutional thinking. The expression of the separation of powers has been used with various implications by historians and political scientists). "

The separation of powers can therefore be understood as constitutional doctrine or limited government doctrine which divides governmental power into branches of legislative, executive and judicial power. The task of legislative power is to make the law, executive power is responsible for carrying out the law and judicial power is responsible for interpreting the law. Closely related and inseparable from this understanding are checks and balances, which say that each branch of government shares its actions. This means that the powers and functions of each branch are separate and run by different people, there is no single agent who can exercise full authority because each depends on each other. This kind of divided power prevents absolutism (as in monarchical or dictatorial powers when all branches are concentrated in a single authority), or prevents the corruption of power arising from the possibility of unattended power.

How to understand the rationale and the doctrine of separation of powers which is essentially a doctrine of constitutionalism or the doctrine of a limited government (limited goverment). Public control or encouragement is almost a small number of people. Effective

control and influence over state power is only possible through the power of the state itself. Thus, a free society must divide power between different and independent authorities. Individual freedom will be maintained if citizens can supervise each other, and if concentration and monopoly power can be prevented. ${ }^{16}$

Meanwhile, according to Han Kelsen, one legal thinker states that the state organ carries out at least one of 2 (two) functions, namely the law creating function or the law applying function or the law applying function (law applying function). By using the kelsen analysis, JimlyAsshiddiqie concluded that after the amendment to the 1945 Constitution of the Republic of Indonesia could be said to be divided into 34 state institutions. Of the 34 countries, there are 28 institutions whose authority is determined both in general and in detail in the 1945 Constitution of the Republic of Indonesia. These 28 State Institutions can be referred to as institutions that have constitutional authority or whose authority has been explicitly given explicitly by the State Constitution Republic of Indonesia, 1945. ${ }^{17}$

The 34 organs can be distinguished from two aspects, namely in terms of function and in terms of hierarchy. The hierarchy between state institutions is

${ }^{16}$ Agus Wahyudi, "Doktrin Pemisahan Kekuasaan Akar Filsafat dan Praktek". Jurnal Hukum Lentera, "Negara \& Kekuasaan, Ed. 8, March, 2005, p. 7-8

${ }^{17}$ Jimly Ashiddiqie, Perkembangan dan Konsolidasi Lembaga Negara Pasca Reformasi, (Jakarta: Sekretariat Jenderal dan Kepanitraan Mahkamah Konsitusi RI, 2006), p. 7-9. 


\section{NOMOI}

\section{LAW REVIEW E-ISSN: 2722-3663

important to determine because there must be a regulation regarding the legal treatment of people who hold positions in that state institution. Which is higher and which is lower needs to be ascertained to determine the seating arrangement at the ceremony and the amount of office allowance for the officials. For this reason, there are two criteria that can be used, namely (1) hierarchical criteria in the form of normative sources which determine their authority, and (II) the quality of their main or supporting functions in the state power system. In connection with this, it can be determined that in terms of function, the 34 institutions, there are those that are primary or primary, and some are secondary or supportive.

While from the hierarchy, the 34 institutions can be divided into three layers. The main layer organ can be called a state high institution. The second layer organ is referred to as a state institution, while the third layer organ is a regional institution. Some of these institutions can be categorized as primary constitutional organs, and some are auxiliary state organs.

Description of the structure of the Indonesian state administration after the amendment to the 1945 Constitution of the Republic of Indonesia follows: The constitution is the highest law in which sovereignty is in the hands of the people and is fully implemented by the Constitution. The Constitution provides a separation of power to six (6) state institutions with an equal and equal position, namely the President, the People's Consultative Assembly (MPR), the House of Representatives (DPR), the Regional Representative Council (DPD), the Supreme Audit Board (BPK), the
Supreme Court (MA) and the Constitutional Court (MK). From a qualitative standpoint, the amendment to the 1945 Constitution of the Republic of Indonesia is fundamental to changing the principles of popular sovereignty that were originally implemented by the MPR to be implemented according to the 1945 Constitution of the Republic of Indonesia.

\section{CONCLUSION}

From the description above, the writer can conclude that in the framework of the Consolidation of the Fifth Amendment of the 1945 Constitution of the Republic of Indonesia will bring the Indonesian people forward and be organized and there will be no more cracks and consolidation will be realized in accordance with the rules of developed and modern countries such as the United States of America as a comparison, and there is no longer the dominance of political parties in determining the direction of the President's policy in making decisions and policies.

The fifth amendment is able to become the basis of national consolidation, because state actors agree that the 1945 Constitution of the State of the Republic of Indonesia is used as the Grund Norm, will be able to bring prosperity to the nation and state, with this fifth amendment able to bring and develop an Indonesian state consisting of various ethnicity, religion, rasm and culture.

The fifth Amendment to the 1945 Constitution of the Republic of Indonesia should be immediately carried out as the nation's cracks have begun to emerge towards the disintegration of the nation through social media. The fifth amendment must be able to consider the philosophical, 
sociological aspects, considering that the Indonesian nation is a very diverse and unique nation that is not possessed by other countries.

\section{REFERENCES}

Ashiddiqie, Jimly. Perkembangan dan Konsolidasi Lembaga Negara Pasca Reformasi, (Jakarta: Sekretariat Jenderal dan Kepanitraan Mahkamah Konsitusi RI, 2006).

, "Sistem Presidensiil Cita Rasa Parlementer", Dialog Kenegaraan di Gedung DPD Kompleks Parlemen, Senayan, Jakarta, diakses pada Jum'at 06 September 2019 pukul 22 : 53 WIB. accessed on Saturday 7 September 2019. Jimly Ashiddiqie, Format of State Institutions and Shifts in Power in the $1945 \quad$ Constitution, (Yogyakarta: FH UII Press, 2005).

Isra, Saldi. "Konsitusi Baru Melalui Komisi Konsitusi: Memastikan Arah Reformasi Konsitusi”, Jurnal Analisi CSIS, tahun XXXI/2002, No. 2.

Jurnal Hukum Kenegaraan, Vol. 2, No. 1, Juni 2019, Konsolidasi Kebangsaan dan Lembaga Negara diterbitkan APHTN-HAN Jawa Timur.

Kusnardi, Moh., Ibrahim, Harmaily, Hukum Tata Negara Indonesia, (Jakarta: Pusat Studi Hukum Tata Negara FH UI, 1998).

MD, Moh, Mahfu. Politik Hukum di Indonesia, (Jakarta: LP3ES, 1998).

Ridhwan, Muhammad., UUD 1945 Kekuasaan Eksekutif Lebih Menonjol (executive heavy), (Jakarta: Haji Masabung, 1998).
Soeroso, Bambang. Focus Group Discusion, International Wildlife Museum \& Rahmad Gallery, J1 S Parman Number 309 Medan, North Sumatra, Friday 18 March 2018,

T.M. Luthfi Yazid, "Komisi-komisi Nasional dalam Konteks Cita-cita Negara Hukum", (paper about Eksistensi Sistem Kelembagaan Negara Pasca Amandemen UUD 1945, organized by the National Law Reform Consortium, at the Aryaduta hotel, Jakarta, September 9, 2004).

The National Legal Development Agency of the Indonesian Ministry of Law and Human Rights. Legal Review of Legal Issues Direct Election of President and Vice President, (Jakarta: Legal Review Team on Legal Issues Election of President and Vice President directly, 2004).

Wahyudi, Agus. "Doktrin Pemisahan Kekuasaan Akar Filsafat dan Praktek". Jurnal Hukum Lentera, "Negara \& Kekuasaan". Ed. 8, 3 March 2005.

www.google.com./amp/s/kbbi.web.id, accessed on Friday, 06 September 2019, 18:14 WIB.

www.hukumonline.com, accessed on Friday, 06 September 2019, pukul 11:50 WIB.

www.liputan6.com, accessed on Friday, 06 september 2019 pukul 11 : 28 WIB. 